\title{
The inlA gene required for cell invasion is conserved and specific to Listeria monocytogenes
}

\author{
Claire Poyart, Patrick Trieu-Cuot and Patrick Berche
}

Author for correspondence: Patrick Berche. Tel: +331406153 79. Fax: +33140615592.

INSERM U.411, Faculté de Médecine Necker-Enfants Malades, 156 rue de Vaugirard, 75724 Paris Cedex 15, France

\begin{abstract}
The Gram-positive bacterium Listeria monocytogenes can actively induce its own uptake by epithelial cells and fibroblasts through a surface-exposed $80 \mathrm{kDa}$ protein, internalin (InIA), encoded by inIA. We studied the distribution and the DNA polymorphism of inIA sequences in a wide variety of wild strains of $L$. monocytogenes as compared to other Listeria species. This was done by PCR-amplifying inIA sequences encoding the fifteen repeats $A$ and the three repeats $B$ of InIA. inIA-repeated sequences were only found in $L$. monocytogenes. The amplified fragment of inIA encoding the repeats $A$ displayed an Alul DNA polymorphism which arises from point mutations. These results indicate that inIA required for cell invasion is specific to $L$. monocytogenes and that the intragenic repeats only exhibit a genetic heterogeneity due to point mutations and not to recombinations.
\end{abstract}

Keywords: Listeria monocytogenes, inl $A$ gene, internalin

\section{INTRODUCTION}

Listeria monocytogenes is a Gram-positive bacterium which is widely distributed in the environment and causes severe food-borne infections in humans and most warm-blooded animals (Gray \& Killinger, 1966). Its pathogenicity is due to its capacity to survive and to multiply in a wide variety of cell types, including macrophages, fibroblasts, epithelial cells, hepatocytes and enterocytes (Mackaness, 1962; Racz et al., 1972; Havell, 1986; Gaillard et al., 1987; Woods et al., 1993). Like other intracellular bacteria, including the Gram-negative Yersinia pseudotuberculosis (Isberg et al., 1987; Isberg \& Leong, 1990), Shigella flexneri (Hale \& Bonventre, 1979) and Salmonella typhimurium (Elsinghorst et al., 1989; Galan \& Curtiss, 1989), L. monocytogenes can actively induce its own uptake by host cells through a specific interaction between a surfaceexposed $80 \mathrm{kDa}$ protein, termed internalin, and an unidentified receptor (Gaillard et al., 1987; Gaillard et al., 1991). The role of internalin has been established by isolating insertion mutants, which are non-adherent and non-invasive (Gaillard et al., 1991). Gene complementation with inl $A$ restores the invasive phenotype of these $L$. monocytogenes mutants and enables the non-invasive species Listeria innocua to penetrate enterocytes (Gaillard et al., 1991). However, inl $A$ has only been characterized in two L. monocytogenes reference strains, EGD and LO28 (Gaillard et al., 1991), and almost nothing is known about the distribution of the gene in clinical isolates of this species.

The gene inl $A$ encodes a protein of 800 amino acids composed, from its amino- to its carboxy-terminus, of a signal peptide, 15 successive repeats of 22 amino acids (repeats A), three successive repeats of 70,70 and 49 amino acids (repeats B), a proline/glycine-rich segment, a hexapeptide (LPTTGD) preceding a stretch of 20 hydrophobic amino acids, and a short positively charged tail (Gaillard et al., 1991; Dramsi et al., 1993) (Fig. 1). Sequence analysis of the segments of inl $A$ encoding regions $A$ and $B$ revealed that they are made up of DNA repeats with an identity of $33-69 \%$ for repeats $A$, and 61-71\% for the repeats B (Table 1) (Gaillard et al., 1991; Dramsi et al., 1993). Several pairs of segments encoding repeats $A$ have in common a region of identity larger than $10 \mathrm{bp}$, and the two contiguous segments coding for repeats $\mathrm{B} 2$ and $\mathrm{B} 3$ share an identical 25 bp motif (Table 1 ). Moreover, Southern blot analysis indicates that $\operatorname{inl} A$ is also part of a gene family (Gaillard et al., 1991). One of them, designated $\mathrm{in} l \mathrm{~B}$, is located immediately downstream of inl $A$ and displays $56 \%$ identity with inl $A$ (Gaillard $e t$ al., 1991). These structural data suggest that inl $A$ might generate variants by intragenic recombination between repeated segments or by extragenic recombination with inl $A$-related sequences, as previously described for the $\mathrm{emm}$ genes of Streptococcus pyogenes encoding the M protein (Fischetti, 1989). 
(a)

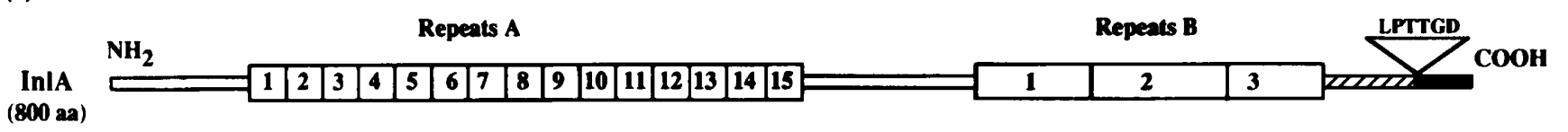

(800 aa)

(b)

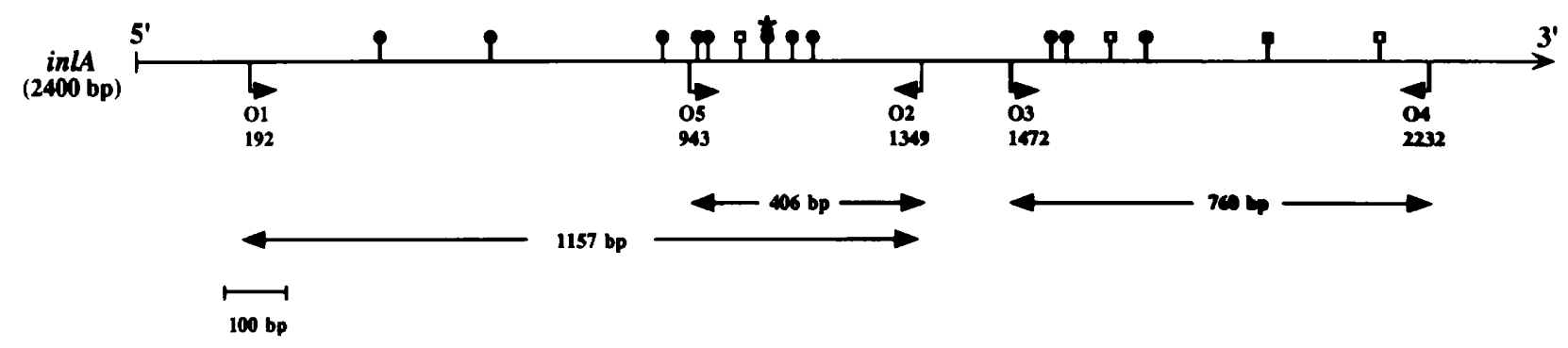

Fig. 1. Structural organization of internalin (a) and partial restriction map of in/A (b). The position of the peptide cleavage site (LPTTGD) is indicated by an open vertical arrow. The hatched and black segments represent the proline/glycine-rich and the hydrophobic membrane-anchored regions, respectively. Repeats $A$ and $B$ are represented by numbered open squares. The positions of the primers 01, 02, 03, 04 and 05 used to amplify inlA repeated sequences are indicated by horizontal black arrows. Only relevant restriction sites are shown: Alul, Accl, HindIII and Rsal restriction sites are indicated by black circles, black squares, black stars and open squares, respectively. Numbering begins at the first base of the initiation codon of inlA (Gaillard et al., 1991; Dramsi et al., 1993).

The aim of this work was to investigate the distribution and DNA polymorphism of inl $A$ in wild, pathogenic and nonpathogenic strains of $L$. monocytogenes and related Listeria species.

\section{METHODS}

Bacterial strains. Sixty-eight strains of L. monocytogenes from various origins were used (Table 2): (i) 19 strains from several reported epidemics, 16 in humans [three from Los Angeles, CA (Linnan et al., 1988), two from the Canton de Vaud, Switzerland (Bille, 1990), three from Nova Scotia, Canada (Fleming et al., 1985), three from Angers, France (Carbonnelle et al., 1978), three from Boston, MA (Schlech et al., 1983) and two from the last epidemic in France in 1992 (Rebière \& Goulet, 1993)] and three in sheep, obtained from Dr Vasquez-Boland, Madrid; (ii) 38 sporadic strains, including 36 strains isolated from human listeriosis cases from various French hospitals during 1987 and 1993 (personal collection) and two strains, one from a human case and one from listeriosis in turkey (Oklahoma, USA), obtained from Dr Swaminathan, Atlanta, GA; (iii) nine strains isolated from cheese or dairy products (INRA, Tours, France) (Tabouret et al., 1991); (iv) the reference strains EGD (Gaillard et al., 1986) and LO28 (Vicente et al., 1985). Most strains belonged to serovar $4 \mathrm{~b}(68 \%)$ and $1 / 2 \mathrm{a}(28 \%)$, the other serovars being $1 / 2 b, 1 / 2 c, 3 a, 3 b, 3 c$ and 7 . All strains isolated from human or animal specimens were virulent in Swiss mice, as tested after intravenous infection $\left(\mathrm{LD}_{50}\right.$ values $10^{4 \cdot 5}-10^{5 \cdot 2}$ bacteria per mouse (unpublished results), whereas the environmental strains were avirulent (Tabouret et al., 1991). We used as controls 10 strains from other Listeria species : L. innocua, four strains (CIP8011 ${ }^{\mathrm{T}}$, SLCC6462, SLCC4202, SLCC4213); Listeria ivanovii, two strains (SLCC4121, CIP7842 ${ }^{\mathrm{T}}$ ); Listeria seeligeri, three strains (CIP100100 ${ }^{\mathrm{T}}$, SLCC3503, SLCC4152); Listeria welshimeri, one strain $\left(\right.$ SLCC5334 $\left.{ }^{\mathbf{T}}\right)$. The following clinical isolates from unrelated bacterial species, isolated from patients (personal collection), were used as controls: Enterococcus faecalis, Streptococcus pyogenes,
Streptococcus pneumoniae, Staphylococcus aureus, Haemophilus inAluenzae, Neisseria meningitidis, Escherichia coli and Pseudomonas aeruginosa. Bacterial strains were grown on brain heart infusion (BHI) broth and BHI agar (Difco), and stored at $-80^{\circ} \mathrm{C}$.

Characterization of inIA repeats $A$ and $B$ by PCR of inIA. PCR was used to amplify the repeats $\mathrm{A}$ and $\mathrm{B}$ of $\mathrm{inl} A$. Total DNA was extracted from each of these strains as described previously (Poyart-Salmeron et al., 1992). For repeats A, we used the pair of primers O1 (5'-GAATGTAACAGACACG-3') and O2 (5'ATCGCTAATAGTAGC-3') to amplify a 1157 bp DNA fragment. For repeats $B$, we used the pair of primers $\mathrm{O} 3\left(5^{\prime}\right.$ AGCCACT'TAAGGCAAT-3') and O4 (5'-AGTTGATGTGTTAGA-3'), to amplify a 760 bp DNA fragment (Fig. 1). The PCR reactions were carried out in a final volume of $100 \mu \mathrm{l}$ containing $50 \mathrm{ng}$ of genomic DNA, $0.5 \mu \mathrm{M}$ of each primer, $200 \mu \mathrm{M}$ of each dNTP (Pharmacia Biotech) and 2.5 U of Taq DNA polymerase (Technomama) in a $1 \times$ amplification buffer [10 mM Tris/HCl (pH 8.3), $50 \mathrm{mM} \mathrm{KCl,} 1.5 \mathrm{mM} \mathrm{MgCl}_{2}$ ]. The PCR mixtures were denaturated $\left(5 \mathrm{~min}\right.$ at $\left.95^{\circ} \mathrm{C}\right)$, then subjected to 40 cycles of amplification ( 1 min of annealing at $55^{\circ} \mathrm{C}, 90 \mathrm{~s}$ of elongation at $72{ }^{\circ} \mathrm{C}$ and $1 \mathrm{~min}$ of denaturation at $\left.94^{\circ} \mathrm{C}\right)$. PCR products were separated by electrophoresis on $1 \%(\mathrm{w} / \mathrm{v})$ agarose gel. Molecular markers (1 kb ladder) were used (Gibco, BRL). The amplified DNA fragments were transferred to Nytran membranes (Amersham), as described by Sambrook et al. (1989). Prehybridization and hybridization under stringent conditions were carried out for $5 \mathrm{~h}$ and $18 \mathrm{~h}$, respectively, at $65^{\circ} \mathrm{C}$ in $6 \times \mathrm{SSC}(1 \times \mathrm{SSC}$ is $0.15 \mathrm{M}$ sodium chloride plus $0.015 \mathrm{M}$ sodium citrate), $0.5 \% \mathrm{SDS} / 0.005 \%$ non-fat dry milk, followed by two washings in $2 \times \mathrm{SSC} / 0 \cdot 1 \% \mathrm{SDS}$ at room temperature for $30 \mathrm{~min}$, and by two washings in $0 \cdot 2 \times$ SSC $/ 0 \cdot 1 \%$ SDS at $68^{\circ} \mathrm{C}$ for $45 \mathrm{~min}$. Southern blot analysis was performed with two probes intragenic to inlA: a $487 \mathrm{bp}$ DraI-HindIII DNA fragment for repeats A, and a $454 \mathrm{bp} R s a \mathrm{I}$ DNA fragment for repeats B (Gaillard $e t$ al., 1991). Labelling of DNA probes with $\left[\alpha_{-}{ }^{32} \mathrm{P}\right] \mathrm{dC}$ TP (Amersham) was carried out by using the Random Priming kit (Amersham). The DNA 
Table 1. Pairwise comparisons of inlA repeated sequences $A 1-A 15$ and $B 1-B 3$.

For each comparison, the percentage of identity is indicated in the first line and the size, in bp, of the longest stretch of identity is indicated in parentheses in the second line. Segments of identity equal to, or larger than, $10 \mathrm{bp}$ are indicated in bold.

\begin{tabular}{|c|c|c|c|c|c|c|c|c|c|c|c|c|c|c|}
\hline & A2 & $A 3$ & A4 & A5 & A6 & $A 7$ & $A B$ & $A 9$ & A10 & A11 & A12 & A13 & A14 & A15 \\
\hline \multirow[t]{16}{*}{ A1 } & 42 & 40 & 42 & 43 & 40 & $\overline{42}$ & 40 & 50 & 36 & 36 & 45 & 39 & 35 & $\overline{44}$ \\
\hline & (3) & (4) & (7) & (3) & (2) & (7) & (5) & (5) & (4) & (4) & (4) & (4) & (4) & (5) \\
\hline & $\overline{A 2}$ & 32 & 60 & 52 & 53 & 51 & 62 & 50 & 51 & 49 & 49 & 56 & 45 & 53 \\
\hline & & (3) & (6) & (9) & (7) & (5) & (8) & (6) & (5) & (6) & (5) & (7) & (5) & (5) \\
\hline & & $\overline{\mathrm{A} 3}$ & 58 & 49 & 62 & 56 & 58 & 56 & 49 & 51 & 64 & 56 & 45 & 55 \\
\hline & & & (8) & (6) & (10) & (5) & (11) & (6) & (6) & (6) & (6) & (7) & (3) & (8) \\
\hline & & & $\overline{\mathrm{A4}}$ & 52 & 65 & 51 & 62 & 58 & 55 & 49 & 51 & 58 & 51 & 55 \\
\hline & & & & (5) & (6) & (7) & (10) & (8) & (9) & (4) & (6) & (7) & (4) & (6) \\
\hline & & & & $\overline{\mathrm{A} 5}$ & 41 & 48 & 63 & 54 & 57 & 57 & 49 & 66 & 55 & 49 \\
\hline & & & & & (6) & (10) & (8) & (7) & (6) & (10) & (8) & (8) & (5) & (6) \\
\hline & & & & & $\overline{A 6}$ & 56 & 55 & 61 & 55 & 48 & 51 & 61 & 47 & 64 \\
\hline & & & & & & (5) & (8) & (8) & (6) & (6) & (5) & (8) & (5) & (13) \\
\hline & & & & & & $\overline{\mathrm{A} 7}$ & 45 & 45 & 33 & 41 & 47 & 53 & 56 & 42 \\
\hline & & & & & & & (5) & (5) & (4) & (6) & (9) & (8) & (9) & (5) \\
\hline & & & & & & & $\overline{\mathrm{AB}}$ & 61 & 61 & 56 & 33 & 64 & 55 & 68 \\
\hline & B2 & B3 & & & & & & (9) & (8) & (9) & (5) & (13) & (7) & (11) \\
\hline \multirow[t]{12}{*}{ B1 } & 66 & 61 & & & & & & $\overline{A 9}$ & 65 & 53 & 58 & 62 & 53 & 61 \\
\hline & (10) & (15) & & & & & & & (7) & (7) & (7) & (11) & (5) & (7) \\
\hline & $\overline{\mathrm{B} 2}$ & 71 & & & & & & & A10 & 61 & 47 & 51 & 47 & 61 \\
\hline & & (25) & & & & & & & & (8) & (4) & (8) & (4) & (8) \\
\hline & & & & & & & & & & $\overline{A 11}$ & 42 & 53 & 45 & 62 \\
\hline & & & & & & & & & & & (5) & (7) & (6) & (11) \\
\hline & & & & & & & & & & & A12 & 59 & 39 & 53 \\
\hline & & & & & & & & & & & & (6) & (3) & (4) \\
\hline & & & & & & & & & & & & $\overline{A 13}$ & 56 & 59 \\
\hline & & & & & & & & & & & & & (7) & (8) \\
\hline & & & & & & & & & & & & & A14 & 49 \\
\hline & & & & & & & & & & & & & & (5) \\
\hline
\end{tabular}

polymorphism of the amplified DNA fragments was studied by enzymic restriction. Amplified fragments $(0.2 \mu \mathrm{g})$ were incubated with 2-3 U of $A l u \mathrm{I}$, HindIII, AccI or RsaI (New England Biolabs) for $2 \mathrm{~h}$ at $37^{\circ} \mathrm{C}$ and the resulting DNA fragments were separated by electrophoresis on $3.5 \%(\mathrm{w} / \mathrm{v})$ metaphor agarose gel (FMC Bioproduct).

Sequence analysis of inlA repeats A. The $406 \mathrm{bp}$ amplified fragments of $i n l A$ repeats $A$ were amplified by using primers $\mathrm{O} 2$ and $\mathrm{O} 5$ (5'-GGT'T'TAACCGCACTCAC-3') and purified from agarose gels by using the QIAE XII kit (Qiagen), treated with DNA polymerase I (Pharmacia) to convert ragged ends to blunt ends, and cloned in both orientations into a $S \mathrm{maI}$-linearized and dephosphorylated replicative form of M13mp18. For each cloning, three clones were sequenced on both strands (Sanger $e t$ al., 1977).

\section{RESULTS AND DISCUSSION}

\section{Amplification of inlA repeats $A$ and $B$ in Listeria species}

The presence of $\operatorname{inl} A$ was studied by amplifying intragenic fragments of repeats $A$ and $B$ in 68 strains of $L$. monocytogenes, as compared to 10 strains of other Listeria species (L. innocua, L. seeligeri, L. ivanovii and L. welshimeri) and eight strains of unrelated Gram-positive and Gramnegative species (E. faecalis, Strep. pyogenes, Strep. pneumoniae, Staph. aureus, $H$. influenzae, N. meningitis, E. coli and $P$. aeruginosa). For each pair of primers specific for intragenic fragments of repeats $\mathrm{A}$ and $\mathrm{B}$ of $\mathrm{inl} A$, a single DNA fragment of the expected size was observed for the 68 
Table 2. Origin of $L$. monocytogenes strains

\begin{tabular}{|c|c|}
\hline Strains & Origin \\
\hline \multicolumn{2}{|c|}{ Reference strains } \\
\hline LO28 & Madrid, Spain (Vicente et al., 1985) \\
\hline EGD & Trudeau Institute, New York (Gaillard et al., 1986) \\
\hline \multicolumn{2}{|c|}{ Epidemic strains* } \\
\hline 850190 & \multirow{3}{*}{ Los Angeles, USA, 1988 (Linnan et al., 1988) } \\
\hline 850203 & \\
\hline 850212 & \\
\hline NEM405 & \multirow{2}{*}{ Switzerland, 1990 (Bille, 1990) } \\
\hline NEM 406 & \\
\hline 820163 & \multirow{3}{*}{ Nova Scotia, Canada, 1985 (Fleming et al., 1985) } \\
\hline 820162 & \\
\hline 820160 & \\
\hline C93 & \multirow{3}{*}{ Angers, France, 1978 (Carbonnelle et al., 1978) } \\
\hline $\mathrm{C} 42$ & \\
\hline $\mathrm{C} 38$ & \\
\hline 830335 & \multirow{3}{*}{ Boston, USA, 1983 (Schelch et al., 1983) } \\
\hline 830336 & \\
\hline 830337 & \\
\hline NEM296 & \multirow{2}{*}{ Paris, France, 1992 (P. Berche, Necker Hospital) } \\
\hline NEM295 & \\
\hline NEM263 & \multirow{3}{*}{ Madrid, Spain, 1992, from sheep (Dr J. A. Vasquez-Boland) } \\
\hline NEM264 & \\
\hline NEM265 & \\
\hline \multicolumn{2}{|c|}{ Sporadic strains* } \\
\hline F6963 & Oklahoma, USA (Dr B. Swaminathan, Atlanta) \\
\hline F6953 & Oklahoma, USA, from turkey (Dr B. Swaminathan, Atlanta) \\
\hline NEM152-180 & France, 1987-1993 (Dr J. Croizé, Grenoble) \\
\hline NEM261-262 & \multirow{2}{*}{ France, $1987-1993$ (P. Berche, Necker Hospital) } \\
\hline NEM266-269 & \\
\hline \multicolumn{2}{|c|}{ Environmental strains } \\
\hline INRA36 & \multirow{8}{*}{ Dr M. Tabouret, France, 1992} \\
\hline INRA49 & \\
\hline INRA50 & \\
\hline INRA64 & \\
\hline INRA85 & \\
\hline INRA35 & \\
\hline INRA41 & \\
\hline INRA61 & \\
\hline NEM270 & Dr A. Audurier, Tours, France, 1987 \\
\hline
\end{tabular}

* All isolates of human origin except where indicated.

strains of L. monocytogenes, including sporadic, epidemic and environmental isolates. These fragments were hybridized under high stringency conditions with intragenic probes of repeats $\mathrm{A}$ and $\mathrm{B}$ of $\mathrm{inl} A$. This is illustrated for 12 representative strains in Fig. 2, including four epidemic, four sporadic and three environmental strains. In contrast, no amplification product was detected with any strain belonging to other Listeria species or to unrelated bacterial species, either by ethidium bromide staining or hybridization with the inl $A$ probe under stringent con- ditions (data not shown). The PCR assay did not detect inl $A$ repeats in the other Listeria species or in various unrelated bacterial species. These results indicate that inl $A$ is constantly present in $L$. monocytogenes, regardless of the origin, serovar and virulence of the isolates. It should be noted that sequences related to $i n l A$ have been detected in the chromosomes of $L$. ivanovii and of the noninvasive species $L$. innocua by DNA-DNA hybridization under low stringency conditions (Gaillard et al., 1991). The gene inl $A$ and the related sequences present in 

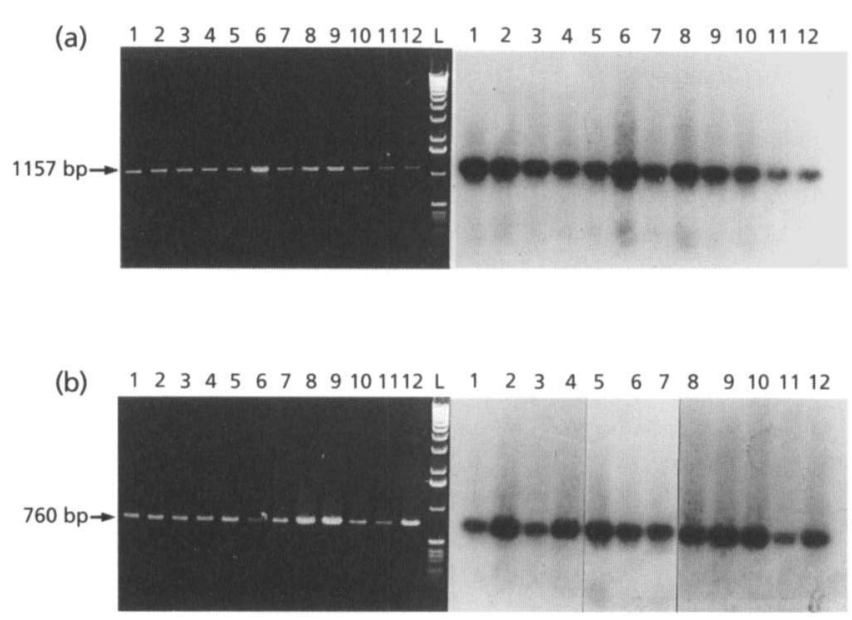

Fig. 2. Analysis by agarose gel electrophoresis (left) and by hybridization (right) of PCR products obtained by using primers amplifying the segments of inIA in L. monocytogenes total DNA encoding the repeats $A$ and $B$ of the corresponding protein. PCR products were separated by electrophoresis on $1 \%$ agarose gel and probed with intragenic probes specific for repeats $A$ or B. Lanes: 1, reference strain EGD; 2-5, epidemic strains C93, NEM296, 850190 and $820163 ; 6-9$, sporadic strains NEM152, NEM153, NEM169 and NEM170; 10-12, environmental strains INRA36, INRA49, INRA50; L, $1 \mathrm{~kb}$ ladder used as molecular size standard.

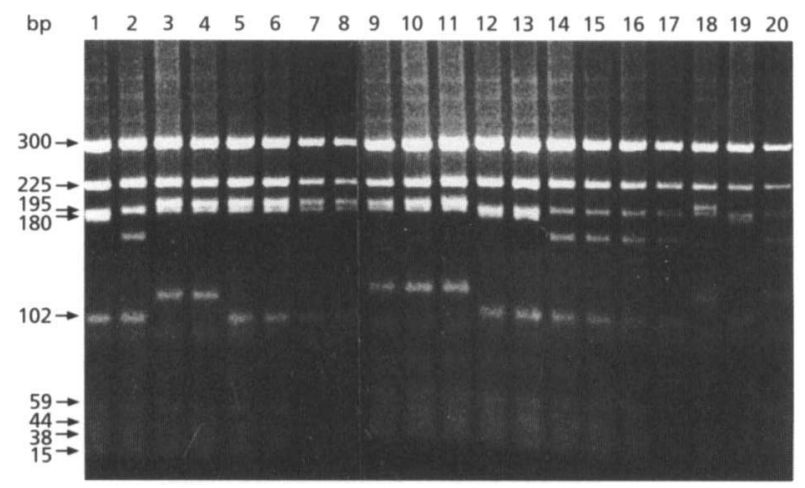

Fig. 3. Analysis by agarose gel electrophoresis (3.5\% agarose) of Alul restriction patterns of PCR products corresponding to the amplified repeats $A$ of inIA in total DNA of 20 strains of $L$. monocytogenes. Lanes: 1 and 2, reference strains EGD and LO28; 3-8, epidemic strains C93, NEM296, 850190, 850203, 820163, 830335; 9-14, sporadic strains NEM152, NEM171, NEM153, NEM169, NEM170 and NEM155; 15-20, environmental strains INRA36, INRA49, INRA50, INRA64, INRA85 and NEM270.

these phylogenetically closely related species are likely to be derived from a common ancestor. This hypothesis implies that these sequences have sufficiently diverged from each other not to allow the detection of inl $A$-related sequences with our PCR assay.

The molecular organization of internalin is analogous to that of certain cell wall proteins from Gram-positive bacteria, especially that of the M protein of Strep. pyogenes. It is known that, in serotype M6, M proteins of different sizes appear to result from intragenic recombination between central repeat blocks of the emm 6 gene (Hollingshead et al., 1986). Recombination between the central repeat blocks results in deletions producing changes in the primary amino acid sequence, which modify antigenic determinants or lead to the loss of an opsonic epitope in the A-repeat region (Jones et al., 1988). Another mechanism involving extragenic recombination between adjacent $\mathrm{emm}$-like genes has also been reported (Haanes \& Cleary, 1989). It is unlikely that such recombinations do occur in L. monocytogenes in view of our results. Indeed, the size of the amplified DNA fragments of repeats A and B of inl $A$ is constant in all 68 isolates of $L$. monocytogenes. Part of this analysis is illustrated in Fig. 2. In fact, antigenic variation has only been described for extracellular pathogens where it allows them to escape the immune system (Robertson \& Meyer, 1992). As a facultative intracellular pathogen, $L$. monocytogenes is slightly exposed to the selective pressure of antibodies, at least at the early phase of infection. Entry into host cells through ligand-receptor interaction might require that internalin be structurally conserved.

\section{Genetic polymorphism of inlA repeats A and B}

The DNA polymorphism of the $L$. monocytogenes amplified DNA fragments of repeats $\mathrm{A}$ and $\mathrm{B}$ of $\operatorname{inl} A$ was then studied by enzymic restriction, using $A l u \mathrm{I}$, HindIII or RsaI. According to the sequence of inl A (Gaillard et al., 1991; Dramsi et al., 1993), there are 10 restriction sites cleaved by these enzymes in this DNA fragment (Fig. 1). The HindIII and RsaI restriction patterns obtained were indistinguishable (data not shown), whereas $A l u \mathrm{I}$ restriction analysis discriminated five different profiles for the $68 \mathrm{~L}$. monocytogenes strains studied. This is illustrated for representative strains in Fig. 3. The sizes of the $A l u \mathrm{I}$ fragments used for reference purposes were those of $i n l A$ from L. monocytogenes EGD (Gaillard et al., 1991; Dramsi et al., 1993) and the corresponding electrophoretic pattern was arbitrarily chosen as defining the type I restriction profile (Fig. 1). Size increase (approx. $27 \mathrm{bp)} \mathrm{or} \mathrm{decrease}$ (approx. $15 \mathrm{bp)}$ of the $180 \mathrm{bp}$ AluI restriction fragment containing $5 \mathrm{bp}$ of repeats A14 and A15, and $109 \mathrm{bp}$ downstream of repeat A15 (Fig. 1) defines the restriction profiles of types II (Fig. 3, lanes 2, 14-17) and III (lanes $5-8,12,13,19)$, respectively. Types IV (Fig. 3, lanes 3, 4, $9-11,18$ ) and V (lane 20) are related to types II and III, respectively, but exhibit a size increase (approx. $12 \mathrm{bp)} \mathrm{of}$ the $102 \mathrm{bp} A l u \mathrm{I}$ fragment which contains $57 \mathrm{bp}$ of A12 and $45 \mathrm{bp}$ of $\mathrm{A} 13$ (Figs 1 and 3). The two AluI segments involved in the observed polymorphism are located in the same region of inl $A$, i.e. that encoding the carboxylic part of the repeats $\mathrm{A}$. This might simply be due to the fact that five out of the eight $A l u \mathrm{I}$ restriction sites present in the segment of inl $A$ coding for the repeats $\mathrm{A}$ are clustered within this region (Fig. 1). A specific profile cannot be associated with the epidemic or sporadic behaviour of the strains, either with their serovars or their virulence. 
Table 3. Differences between the amplified $406 \mathrm{bp}$ DNA fragment of inlA encoding the repeats $A 11-A 15$ from $L$. monocytogenes strains representative of the five Alul restriction profiles

\begin{tabular}{|c|c|c|c|c|c|c|}
\hline \multirow[t]{2}{*}{ Base no.* } & \multicolumn{6}{|c|}{ Codon $\dagger$ and corresponding amino acid } \\
\hline & EGD $\ddagger$ & $\begin{array}{c}\text { EGD } \\
\text { (type I) } ₫\end{array}$ & $\begin{array}{c}\text { L028 } \\
\text { (type II)』 }\end{array}$ & $\begin{array}{c}850190 \\
\text { (type III)ऽ }\end{array}$ & $\begin{array}{c}\text { C93 } \\
\text { (type IV) } \$\end{array}$ & $\begin{array}{l}\text { NEM270 } \\
\text { (type V) }\end{array}$ \\
\hline 966 & TTa/L & & & & & $\mathrm{TTt} / \mathrm{F}$ \\
\hline 972 & $\mathrm{CTt} / \mathrm{L}$ & & & & $\mathrm{CTa} / \mathrm{L}$ & $\mathrm{CTa} / \mathrm{L}$ \\
\hline $985 / 987$ & $\mathrm{c} T g^{\top} / \mathrm{L}$ & & & $\mathrm{cTa} / \mathrm{L}$ & $\mathrm{tTa} / \mathrm{L}$ & $\mathrm{tTa} / \mathrm{L}$ \\
\hline 1035 & $\mathrm{ACg} / \mathrm{T}$ & & $\mathrm{ACt} / \mathrm{T}$ & $\mathrm{ACt} / \mathrm{T}$ & & \\
\hline 1143 & $\mathrm{AAc} / \mathrm{N}$ & & & & AAt $/ \mathrm{N}$ & \\
\hline 1149 & $\mathrm{ACc} / \mathrm{T}$ & & $\mathrm{ACa} / \mathrm{T}$ & $\mathrm{ACa} / \mathrm{T}$ & & \\
\hline 1167 & $\mathrm{TCa} / \mathrm{S}$ & & & $\mathrm{TCg} / \mathrm{S}$ & $\mathrm{TCg} / \mathrm{S}$ & \\
\hline 1170 & $\mathrm{GCt} / \mathrm{A}$ & & & $\mathrm{GCc} / \mathrm{A}$ & & \\
\hline 1221 & $\mathrm{ATc} / \mathrm{I}$ & & & & $\mathrm{ATt} / \mathrm{I}$ & \\
\hline 1222 & $\mathrm{aCC} / \mathrm{T}$ & & & $\mathrm{gCC} / \mathrm{A}$ & & \\
\hline 1228 & cTA/L & & & & $\mathrm{tTA} / \mathrm{L}$ & \\
\hline 1233 & $\mathrm{GGg} / \mathrm{G}$ & & & & GGa/G & \\
\hline 1242 & GAt/D & & & & GAc/D & \\
\hline 1247 & GcA/A & & & & $\mathrm{GaA} / \mathrm{E}$ & \\
\hline 1258 & $\mathrm{gCA} / \mathrm{A}$ & & & & $\mathrm{cCA} / \mathrm{P}$ & \\
\hline 1266 & $\mathrm{GTa} / \mathrm{V}$ & & & & $\mathrm{GTg} / \mathrm{V}$ & \\
\hline 1277 & GcA/A & & & & $\mathrm{GtA} / \mathrm{V}$ & \\
\hline 1281 & $\mathrm{AAt} / \mathrm{N}$ & & & & & $\mathrm{AAc} / \mathrm{N}$ \\
\hline 1283 & $\mathrm{GtA} / \mathrm{V}$ & & & GcA/A & & \\
\hline 1314 & $\mathrm{ACt} / \mathrm{T}$ & & & $\mathrm{ACg} / \mathrm{T}$ & $\mathrm{ACg} / \mathrm{T}$ & \\
\hline 1317 & GGc/G & & & & & GGt/G \\
\hline 1323 & $\mathrm{TTg} / \mathrm{L}$ & & $\mathrm{TTa} / \mathrm{L}$ & & & \\
\hline 1332 & $\mathrm{CCt} / \mathrm{P}$ & $\mathrm{CCa} / \mathrm{P}$ & $\mathrm{CCa} / \mathrm{P}$ & $\mathrm{CCa} / \mathrm{P}$ & $\mathrm{CCa} / \mathrm{P}$ & $\mathrm{CCa} / \mathrm{P}$ \\
\hline
\end{tabular}

* Numbering refers to the first base of the ATG codon of the revised sequence of inlA (Gaillard et al., 1991 ; Dramsi et al., 1993) and indicates the position of nonidentical bases.

fIdentical and nonidentical nucleotides in the codons are written in upper and lower case, respectively. $\ddagger$ Data are from Gaillard et al. (1991).

$\S$ Data are based on the sequence determination of the amplified 409 bp DNA fragments. Only the codons which differ from those of the revised sequence of inl $A$ (Gaillard et al., 1991; Dramsi et al., 1993) are shown.

The DNA polymorphism of the $760 \mathrm{bp}$ amplified DNA fragment encoding the repeats $B$ was studied similarly following digestion with $A c c \mathrm{I}, A l u \mathrm{I}$ or RsaI endonucleases. There are six restriction sites cleaved by these enzymes in this DNA fragment (Fig. 1). The restriction patterns obtained with each of the three enzymes were indistinguishable for all $68 \mathrm{~L}$. monocytogenes strains (data not shown).

\section{Characterization of inlA variants}

In an attempt to elucidate the molecular basis of the $A l u \mathrm{I}$ polymorphism, we amplified a 406 bp DNA fragment of inl $A$ encoding the repeats $\mathrm{A} 11-\mathrm{A} 15$ from $L$. monocytogenes strains (EGD, LO28, 850190, C93, NEM270) representative of the five types of $A$ luI restriction profiles (I, II, III, IV and V, respectively) by using the primers O5 and $\mathrm{O} 2$ (Fig. 1). The amplified DNA fragments were purified from each amplification mixture, cloned into M13mp18 and sequenced entirely. Comparison of their nucleotide sequences with that of the corresponding segment of $\operatorname{inl} A$ from $L$. monocytogenes EGD (Gaillard et al., 1991; Dramsi et al., 1993) taken as a reference, revealed that they differ at 24 positions which are located in 23 codons (Table 1). Surprisingly, the amplified DNA fragment obtained from $L$. monocytogenes EGD differed at one position from the previously published sequences (Gaillard et al., 1991; Dramsi et al., 1993). However, since the same mutation was found in the four other sequences determined (Table 3), it is unlikely that it results from misincorporation of nucleotides during the PCR assay. The amplified DNA fragments representative of the five restriction profiles characterized have the same size and their nucleotide sequences are highly related (the level of identity is $\geqslant 96 \%$ depending on the sequences con- 
sidered). Thus, the observed DNA polymorphism most likely results from point mutations and not from intragenic recombination within inl $A$ or from extragenic recombination between $\operatorname{inl} A$ and the highly divergent inl $A$-related sequences. Among the 13 mutations located in the region encoding $A 11-A 15,11$ were silent and the remaining two at positions 966 and 1222 maintained a similarly charged residue at the same place (Table 1). Eleven mutations were located in the $109 \mathrm{bp}$ sequence downstream of the region coding for A15. Of these changes, six mutations were silent and the substitutions at positions 1258, 1277 and 1283 maintained a similarly charged residue at the same place (Table 1). Only the change at position 1247 corresponds to a nonequivalent amino acid replacement: alanine (EGD, LO28, 850190 and NEM270) versus glutamic acid (C93). Since strain C93 was isolated from an epidemic and is therefore virulent, it is assumed that this mutation has not led to modification of the functionality of InlA. In conclusion, our results show that inl $A$ required for invasion is specific to $L$. monocytogenes and that the intragenic repeats only exhibit a genetic heterogeneity due to mutations and not to recombinations.

\section{ACKNOWLEDGEMENTS}

We are grateful to Dr Croizé (Grenoble), Dr Swaminathan (Atlanta), Dr Audurier (Tours), Dr Bille (Genève), Dr Tabouret (Tours) and Dr Vasquez-Boland (Madrid) for the gift of $L$. monocytogenes strains. R. Fournier is also thanked for typing the manuscript. This work was supported by INSERM, the University Paris V and the Fondation pour la Recherche Médicale.

\section{REFERENCES}

Bille, J. (1990). Epidemiology of human listeriosis in Europe, with special reference to the Swiss outbreak. In Foodborne Listeriosis, pp. 71-74. Edited by A. J. Miller, J. L. Smith \& G. A. Somkuti. New York: Society for Industrial Microbiology/Elsevier Science Publishing.

Carbonnelle, B., Cottin, J., Parvery, F., Chambreuil, G., Kouyoumdhan, S., Le Lirzin, M., Cordier, G. \& Vincent, T. (1978). Epidémie de listériose dans l'ouest de la France (1975-1976). Rev Epidemiol Sante Publique 26, 451-467.

Dramsi, S., Deboux, P. \& Cossart, P. (1993). Common features of Gram-positive bacterial proteins involved in cell recognition. Mol Microbiol 9, 1119-1122.

Elsinghorst, E. A., Baron, L. S. \& Kopecko, D. J. (1989). Penetration of human intestinal epithelial cells by Salmonella: molecular cloning and expression of Salmonella typhi invasion determinants in Eschericbia coli. Proc Natl Acad Sci USA 86, 5173-5177.

Fischetti, V. A. (1989). Streptococcal M protein: molecular design and biological behavior. Clin Microbiol Rev 2, 285-314.

Fleming, D. W., Cochi, S. L., MacDonald, K. L., Brondum, J., Hayes, P. S., Plikaytis, B. D., Holmes, M. B., Audurier, A., Broome, C. \& Reingold, A. L. (1985). Pasteurized milk as a vehicle of infection in an outbreak of listeriosis. New Engl J Med 312, 404-407.

Gaillard, J. L., Berche, P. \& Sansonetti, P. (1986). Transposon mutagenesis as a tool to study the role of hemolysin in the virulence of Listeria monocytogenes. Infect Immun 52, 50-55.

Gaillard, J.-L., Berche, P., Mounier, J., Richard, S. \& Sansonetti, P.
(1987). In vitro model of penetration and intracellular growth of Listeria monocytogenes in the human enterocyte-like cell line Caco-2. Infect Immun 55, 2822-2829.

Gaillard, J.-L., Berche, P., Fréhel, C., Gouin, E. \& Cossart, P. (1991). Entry of $L$. monocytogenes into cells is mediated by internalin, a repeat protein reminiscent of surface antigens from gram-positive cocci. Cell 65, 1127-1141.

Galan, J. E. \& Curtiss, R., III (1989). Cloning and molecular characterization of genes whose products allow Salmonella typhimurium to penetrate tissue culture cells. Proc Natl Acad Sci US A 86, 6383-6387.

Gray, M. L. \& Killinger, A. H. (1966). Listeria monocytogenes and listeric infections. Bacteriol Rev 30, 309-382.

Haanes, E. J. \& Cleary, P. P. (1989). Identification of a divergent M protein gene and an $\mathrm{M}$ protein-related gene family in Streptococcus pyogenes serotype 49. J Bacteriol 171, 6397-6408.

Hale T. L. \& Bonventre, P. F. (1979). Shigella infection of Henle intestinal epithelial cells: role of the bacterium. Infect Immun 24, 879-886.

Havell, E. A. (1986). Synthesis and secretion of interferon by murine fibroblasts in response to intracellular Listeria monocytogenes. Infect Immun 54, 787-792.

Hollingshead, S. K., Fischetti, V. A. \& Scott, J. R. (1986). Complete nucleotide sequence of type $6 \mathrm{M}$ protein of the group A streptococcus: repetitive structure and membrane anchor. $J$ Biol Chem 261, 1677-1686.

Isberg, R. R. \& Leong, J. M. (1990). Multiple $\beta_{1}$ chain integrins are receptors for invasin, a protein that promotes bacterial penetration into mammalian cells. Cell 60, 861-871.

Isberg, R. R., Voorhis, D. L. \& Falkow, S. (1987). Identification of invasin: a protein that allows enteric bacteria to penetrate cultured mammalian cells. Cell 50, 769-778.

Jones, K. F., Hollingshead, S. K., Scott, J. R. \& Fischetti, V. A. (1988). Spontaneous M6 protein size mutants of group A streptococci display variation in antigenic and opsonogenic epitopes. Proc Natl Acad Sci US A 85, 8271-8275.

Linnan, M. J., Mascola, L., Lou, X. D., Goulet, V., May, S., Salminen, C., Hird, D. X., Yonekura, M. L., Hayes, P., Weaver, R., Audurier, A., Pilikaytis, B. D., Fannin, S. L., Kleks, A. \& Broome, C. V. (1988). Epidemic listeriosis associated with Mexican-style cheese. $N$ Engl J Med 319, 823-828.

Mackaness, G. G. (1962). Cellular resistance to infection. $J$ Exp Med 116, 381-406.

Poyart-Salmeron, C., Trieu-Cuot, P., Carlier, C., MacGowan, A., McLauchlin, J. \& Courvalin, P. (1992). Genetic basis of tetracycline resistance in clinical isolates of Listeria monocytogenes. Antimicrob Agents Chemother 36, 463-466.

Racz, P., Tenner, K. \& Mero, E. (1972). Experimental Listeria enteritis. I. An electron microscopic study of the epithelial phase in experimental Listeria infection. Lab Invest Meth Cell Biol 26, 694-700.

Rebière, I. \& Goulet, V. (1993). La listériose: revue générale et référence à l'épidémie française de 1992. Lett Infectiol 8, 130-135.

Robertson, B. D. \& Meyer, T. F. (1992). Genetic variation in pathogenic bacteria. Trends Genet 8, 422-427.

Sambrook, J., Fritsch, E. F. \& Maniatis, T. (1989). Molecular cloning: a laboratory manual, 2nd edn. Cold Spring Harbor, NY: Cold Spring Harbor Laboratory.

Sanger, F., Nicklen, S. \& Coulson, A. R. (1977). DNA sequencing with chain-terminating inhibitors. Proc Natl Acad Sci USA 74, 5463-5467. 
Schlech, V. F., Lavigne, P. M., Bortolussi, R. A., Allen, A. C., Haldane, E. V., Wort, A. J., Hightower, A. W., Johnson, S. E., King, S. H., Nicholls, E. S. \& Broome, C. V. (1983). Epidemic listeriosis - evidence for transmission by food. N Engl J Med 308, 203-206.

Tabouret, M., Rycke, J., Andurier, A. \& Poutrel, B. (1991). Pathogenicity of Listeria monocytogenes isolates in immunocompromised mice in relation to listeriolysin production. $J \mathrm{Med}$ Microbiol 34, 13-18.
Vicente, M. F., Baquero, F. \& Perez-Diaz, J. C. (1985). Cloning and expression of the Listeria monocytogenes haemolysin in E. coli. FEMS Microbiol Lett 30, 77-79.

Woods, S., Maroushek, N. \& Czuprynski, C. J. (1993). Multiplication of Listeria monocytogenes in a murine hepatocyte cell line. Infect Immun 61, 3068-3072.

Received 23 May 1995; revised 3 August 1995; accepted 23 August 1995. 